Jap. J. of Edu. Psychol. Vol. II, No. 4 (1954)

\title{
I 「要求調查」から見た僻地の子供達*
}

$\begin{array}{ccccc}\text { 塚 } & \text { 田 } & & \text { 毅** } \\ \text { 久 } & \text { 保 } & \text { 田 } & \text { 正 } & \text { 人 }\end{array}$

\section{〔1]問题}

どの様な条件の下にある地域を「僻地」と称したらよい かということは根本的に検討を要することであるが，一 般的に「僻地」の概念に含まれる条件は先ず自然的・地 理的条件であり，それに対応する文化的条件，経济的条 件等である***。しかし我々が教育の立場から僻地の児 童・生徒の実態を知ろうとする時, 重要な問題の 1 つと なるのは，鉄道から 27 キロも離れている山間の分校に 学んでいる子供であるとか, 生れてから一度も汽車を見 たととのない子供であるとか，同学年の粐友を 2 人しか 持たない子供であるとかいらととだけでなく，その様な 環境的制約の下にある生活体験が子供達の心理学的生活 窒間安如何に規定し, 子供達の態度や行動に如何なる影 響を与えているかということであろう。何となれば，僻 地の子供達の生活空間と都会の子供達のそれがどの様な 点で異つているかということが解るならば，我々は僻地 の子供達に対卞る学習指導の方法を問題とする時に教師 の態度や技術が如何にあるべきかを考える上の有力な手 掛りが得られるであろうからである。

そこで我々は，今回の調查に当り，塚田がかつて要求 に関する一研究****のために作製してて若干の調査資料を 有する「要求調查」（後述の $\mathrm{A}$ 票形式）を僻地の子供達 について実施し，その結果を都会児童の場合と比較して 見ることにした。「要求調查」は次項に揭げる様に「ほ しいもの」「したいこと」及び「なりたいもの」につい

* Results of "Need Test" on Isolated Village School-children

** by Tsukada, Takeshi (Tohoku University) and Kubota, Masando (Tohoku University). 全 体のまとめを塚田が，素材の整理を久保田が分担し， 執筆には塚田が当つた。

*** (1) 交部省, わが国教育の現状一一教育の機会均 等を主として一，昭 28, p. 94

（2）文部省初等中等教育局，一き地教育の実態，調查 報告 I, 昭 28, p. $60 \mathrm{f}$ 。

***** 塚田, 要求の持続度の研究, 昭 27 , 未発表。
て何でも可能ならという仮定の下に自由に答えさせるテ ストである。そこでは, 要求の対象を考えて回答するに 当たり，形式的には何等の制約もないところのあらゆる 自由性が与えられているのであるが，その様な自由度が どの子供にとつても同様の意味をもつとは云い得ない。 それが実際の行動——こ場合にはこの様な質問につい て考えて答えること一の上にどの様に生かされるかと いうことは, 回答する子供の心理学的な生活空間の分化 度の如何，即ち現実層に対して願望とか希望とか想像と かの世界の成立を可能ならしめる非現実層が如何なる程 度に分化しているかによつて異つて来る場合があるであ ろう。そしてその様な生活空間の層構造の如何, 分化度 の如何を規定する条件として子供達の年齢的な発達段階 と共に重要なものは, 子供達の日常の生活体験でなけれ ばならない。

以上の様に考えてごの調查を実施した。そして昭和 28 年度に得られた鬼首・網地島両地区 (营城県) の調查結 果の一部については, 先頁塚田の要求と体験との相互規 定性の研究に関連して発表し*, 或いは他部門との共同 で発表した**。ここで報告するむのは, 更に昭和29年度 において続けて央施した東通”(青森県)・沢内(岩手県) 両地区の資料が加わつており，「要求調查」の手続きの上 にも新たな考慮——後述の $\mathrm{B}$ 票形式のテストの㨀入一 が加わつている。

\section{〔2〕手続きと結果}

（A）A票による「要求調查」について

1. 調查の実施

調查対象の地区別・学年別・男女别人数は Table 3 の 通りである。即ち学年は小学 4 年・ 6 年及び中学 2 年を 選んだ。

* 塚田・久保田, 要求々体験一一第 3 報告, 日本心 理学会第18回大会報告, 昭29。

*** 東北大学共同研究, 僻地教育の現状とその対策,

日本教育学会第13回大会報告, 昭29。 
Table 3 地区・学年・男女别調查人員

\begin{tabular}{|c|c|c|c|c|c|c|c|}
\hline & \multicolumn{2}{|c|}{ 小学 4 年 } & \multicolumn{2}{|c|}{ 小学 6 年 } & \multicolumn{2}{|c|}{ 中学 2 年* } & \multirow{2}{*}{ 計 } \\
\hline & 女 & 男 & 女 & 男 & 女 & 男 & \\
\hline 鬼首地区 & 36 & 31 & 27 & 30 & 25 & 26 & 175 \\
\hline 沢内地区 & 39 & 43 & 28 & 43 & 53 & 52 & 258 \\
\hline 東通地区 & 27 & 15 & 26 & 23 & 11 & 24 & 126 \\
\hline 網地島地区 & 44 & 37 & 37 & 49 & 31 & 20 & 218 \\
\hline 計 & 146 & 126 & 118 & 145 & 120 & 122 & 777 \\
\hline & 25 & 28 & & & 31 & 20 & 104 \\
\hline 東 & 36 & 43 & 28 & 26 & & & 133 \\
\hline 計 & 61 & 71 & 28 & 26 & 31 & 20 & 237 \\
\hline
\end{tabular}

*鬼首地区では都合により中学 3 年生を対象とした。

調查に用いた「要求調查」A票の内容: $大$ Table 4 の如 くである。この様な形式の質問紙に対して教室:おおて 筆答せしめた。時間の制限泣設けなかつたが，大体40分 以内:答え終るのが普通であつた。

\section{Table 4}

\section{要 求調查 $\mathrm{A}$}

調查日 昭和 年月日学校年 組 姓名满歳 月 つぎの質閂に思つたとまり答えて下さい

（1）もしまなたは何でも手に入るとしたら

一ばんほしいものは何ですか

二ばんめにほしいものは何ですか

三がんめにほしいものは何ですか

(2)もしあなたは何でもできるとしたら

一汭んしたいことは何ですか

二ジんめにしたいことは何ですか

三ジんめにしたいことは何ですか

(3)もしあなた怕何にでもなれるとしたら

一ばんなりたいものは何ですか

二ばんめになりたいものは何ですか（

三汭んめになりたいものは何ですか

（漢字にはかなを附けてあり，また一通り涜ん できかせたう

この調查は成續等こ開係しないてとを説明し，できる ェ゙け気楽な空気の中で答えさせる様汇配慮しだ。質問事 項の説明の際趣旨を子供達㓅よ納得させるため:に, 4 年生で、担任教師から方言等をまじえた゚だけた説明を してきらつたこともある。

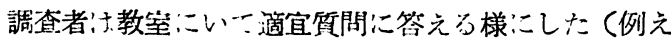

ば「どこにもないものを畫いてもいいですか」と間われ れば，「英際になくても欲しいと思う物なら何でもよい」 と答光る)。

\section{2. 結果の整理}

\section{a 回答の稙類と頻数から見た各地区の傾向}

先ず得られた多様な語異を見易い様に整理した。ここ では個人の特徵を当面の問題とせず, 全体の傾向をつか もうとしたのである。答は 1 人 1 問について 3 箇が原則

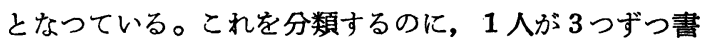
いている答をばらして，例えば鬼首地区の 4 年生の男の むのとして一緒にして取扱つた。この際，iうの質間に 対して出て来る 3 つの答の序列は特に問題にしなかつ た。1問について3つずつ書かせる様にしたのは，なる ベく広く傾向を見ようとしたためである。

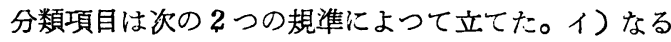
べく客観的・記述的㐳分類項目を作ること。口) 答の中 に出現する頻数の多いものを項目として立てること。だ から細い具体的な項目が抽象的な項目と並ぶこともあ る。この様にして Table 5，6，7が作られたが，反応 語が種々様々であることと時間や人手の不足等から，項 目の設定に精粗や交錯があり，筆者自身にとつても十分 满足なものとはなつていない。なおこの様に整理して見 ると，後に述べる如き我々がここで特に取り上げる傾向 以外にも色々と注目すべき点があるので，繁をいとわず 全項目について表示してある。地区け左から山村 (鬼首 ・沢内）・潐村（東通・網地島）・都会の順に並べた。 各学年男女の闌で女が先に来ている訳は「考察」の所で 述べる。

以下表の項目について必要と思われる説明安行う。。 第 1 問 (核しいもの)—Table 5

1.1. [学用品]「学用品」・「觔強の道具」等と答え たもの。

1．2. 鉛筆・けしごむ・帳面・下敷等，細々とした普 通誰でも持つているもの。

2.1.〔本]単に「本」と答えたもの。

2. 2.〔規定詞のついたもの〕雑誌・小説・「為になる 本」等。

3.〔身につけるもの]着物・洋服・オ゚ーバー・靴下等。

4.〔身の廻りの品了漠然とした項目 ご，机・本箱・ 家庭用品・鞄等が入る。

5. 立派な家・勉強部屋等。

8.1.[単純なもの]お手玉・めんこ・少沈じき等。

8. 2.【比較的手のこ儿だもの】汽車模型・捕虫網等。

12. 2.〔八モニカ・木琴等〕は 12.1. に対して比較的 入手容易で大竞的去ものである。 
Table 5

\begin{tabular}{|c|c|c|c|c|c|c|c|c|c|c|c|c|c|}
\hline & \multirow{3}{*}{ 第 1 問 ほしいる。 } & \multicolumn{6}{|c|}{ 鬼 首 地 区（宮城県） } & \multicolumn{6}{|c|}{ 沢 内 地 区 (岩手県) } \\
\hline & & \multicolumn{2}{|c|}{ 小学 4年 } & \multicolumn{2}{|c|}{ 小学 6 年 } & \multicolumn{2}{|c|}{ 中学 3年 } & \multicolumn{2}{|c|}{ 小学 4年 } & \multicolumn{2}{|c|}{ 小学 6 年 } & \multicolumn{2}{|c|}{ 中学 2 年 } \\
\hline & & 女 & 男 & 女 & 男 & 女 & 男 & 女 & 男 & 女 & 男 & 女 & 男 \\
\hline \multirow{2}{*}{1} & 学用品 $\{1$. 学用品 & 2.6 & 1. 1 & 2.5 & 1.1 & 6.3 & 1.3 & 0.9 & 3. 8 & 4.8 & 4. 7 & 3. 1 & 2.6 \\
\hline & ２．鉊筆，けしごを，帳面の類 & 32.4 & 24. 7 & 1.2 & $2 . ?$ & 5. 3 & 0 & 6. 8 & 7.6 & 1.2 & 0 & 0 & 0 \\
\hline \multirow{2}{*}{2} & 本 $\{1$. 本 & 15.7 & 8. 6 & 9.9 & 8. 9 & 0 & 2.6 & 6. 0 & 7.6 & 5. 0 & 5.5 & 5.7 & 3. 2 \\
\hline & × 2. 規定詞のついたもの & 0 & 8.6 & 4. 8 & 3.3 & 6.3 & 5. 1 & 12.0 & 6.8 & 17. 9 & 6.2 & 6.9 & 7. 7 \\
\hline 3 & 身につけるもの & 25.9 & 3.2 & 32.1 & 5.6 & 17. 4 & 3. 9 & 32.5 & $3: 8$ & 22.7 & 5.5 & 21.4 & 3. 2 \\
\hline 4 & 身の廻りの品 & 3.7 & 4. 3 & 2.5 & 2. 2 & 2. 7 & 2.6 & 8.6 & 6. 1 & 9.5 & 2.3 & 5.0 & 1.3 \\
\hline 5 & 家, 部屋 & 0.9 & 0 & 2. 5 & 1. 1 & 2.7 & 0 & 0 & 1.5 & 1.2 & 3.1 & 4. 4 & 4.5 \\
\hline 6 & 金, 財産 & 0 & 2. 7 & 8.7 & 7. 8 & 4. 0 & 5. 1 & 4. 3 & 6.8 & 5.0 & 6. 2 & 6.9 & 2.6 \\
\hline 7 & 宝石 & 0 & 0 & 0 & 0 & 0 & 0 & 0 & 0 & 0 & 1.6 & 0 & 0 \\
\hline \multirow{2}{*}{8} & 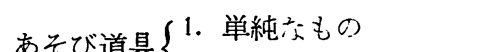 & 10. 2 & 8. 6 & 0 & 2. 2 & 0 & 0 & 5.1 & 0 & 2.4 & 1.6 & 0 & 1.3 \\
\hline & 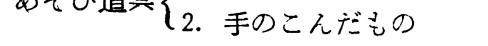 & 0 & 0 & 0 & 0 & 0 & 0 & 0.9 & 1.5 & 0 & 1.6 & 0 & 3. 8 \\
\hline 9 & 人 形 & 0.9 & 2. 2 & 3. 7 & 0 & 1.3 & 0 & 3. 4 & 0 & 3.6 & 0 & 0 & 0 \\
\hline & スポーツ用品 $\{1$. 野球用 & 0 & 12.9 & 0 & 17.8 & 0 & 0 & 0 & 6.8 & 0 & 13. 2 & 0 & 8. 4 \\
\hline & 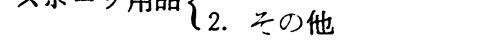 & 0.9 & 2.2 & 1. 2 & 7.8 & 0 & 1.3 & 3. 4 & 0.8 & 1. 2 & 1.5 & 2. 0 & 2.6 \\
\hline 11 & 桧画材料 & 0 & 0 & 0 & 0 & 0 & 0 & 2.6 & 1.5 & 1. 2 & 0 & 0 & 0 \\
\hline \multirow{2}{*}{12} & 楽器 $\{1$. ピアノ，オルガン等 & 0.9 & 1. 1 & 4. 9 & 1. 1 & 2. 7 & 0 & 0.9 & 1.5 & 2. 4 & 1.6 & 1. 2 & 0 \\
\hline & 果砳 $\{$ 2. ハーモニカ, 木琴等 & 0 & 0 & 0 & 1.1 & 2. 7 & 2.6 & 0 & 0 & 1. 2 & 4.7 & 8. 8 & 3.2 \\
\hline \multirow{4}{*}{13} & 裁縫道县 $\{1$. ミシン & 0 & 0 & 1.2 & 0 & 10.7 & 0 & 2.6 & 0 & 1. 2 & 0 & 5.7 & 0 \\
\hline & 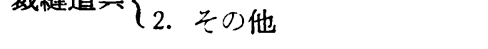 & 0 & 0 & 0 & 0 & 1.3 & 0 & 1.7 & 0.8 & 0 & 0 & 0.6 & 1.3 \\
\hline & (1. ラジオ & 0 & 1.1 & 0 & 5.6 & 0 & 3. 9 & 0 & 0 & 1. 2 & 2. 3 & 2.0 & 1.9 \\
\hline & 2. テレビ & 0 & 0 & 4. 5 & 6.8 & 4. 8 & 0 & 0 & 0.8 & 1. 2 & 1.6 & 0.6 & 3.8 \\
\hline \multirow[t]{3}{*}{14} & 文化的備品 3 . 時計 & 0 & 0 & 0 & 0 & 0 & 16. 9 & 0 & 3.8 & 0 & 3. 1 & 0 & 3.2 \\
\hline & 4. カメラ & 0 & 1.1 & 0 & 1.1 & 0 & 17. 9 & 0.9 & c) & 0 & 0.8 & 0.6 & 1.3 \\
\hline & 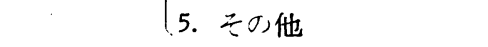 & 0 & 1. 1 & 0 & 2. 2 & 0 & 0 & 0 & 0 & 2. 4 & 1.6 & 0.6 & 0.6 \\
\hline 15 & 船 & 0 & 0 & 2.5 & 2. 2 & 0 & 0 & 2.6 & 2.3 & 0 & 3.1 & 2. 0 & 4.5 \\
\hline \multirow{2}{*}{16} & 車 $\{1$. 自転車 & 0 & 1. 1 & 0 & 1.1 & 9.4 & 23. 1 & 0 & 0 & 1. 2 & 7.0 & 0.6 & 5.8 \\
\hline & 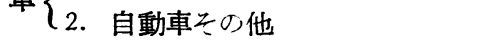 & 0 & 1. 1 & 2.5 & 7.8 & 0 & 2.6 & 0 & 5.3 & 0 & 4. 7 & 0.6 & 10.9 \\
\hline 17 & 飛行機 & 0 & 1.1 & 0 & 3.3 & 0 & 0 & 0.9 & 0 & 0 & 1.6 & 0.6 & 6.4 \\
\hline 18 & 機械類 & 0 & 0 & 0 & 0 & 0 & 0 & 0 & 5.3 & 0 & 7.0 & 0 & 3. 2 \\
\hline 19 & 動物 & 0.9 & 0 & 0 & 1.1 & 0 & 0 & 0 & 0.8 & 0 & 1.6 & 0.6 & 0 \\
\hline 20 & 植物 & 0 & 0 & 0 & 0 & 0 & 0 & 0 & 0.8 & 0 & 0 & 1. 2 & 0 \\
\hline 21 & たベもの & 3.7 & 3.2 & 2.5 & 0 & 1. 3 & 3.9 & 0 & 2. 3 & 3.6 & 1.6 & 1. 2 & 0.6 \\
\hline 22 & 魔法 & 0 & 0 & 0 & 0 & 0 & 0 & 0.9 & 2.3 & 0 & 0 & 0 & 0.6 \\
\hline 23 & 精神や能力 & 0 & 0 & 0 & 0 & 0 & 0 & 0 & 1.5 & 0 & 0 & 2. 0 & 1.9 \\
\hline \multirow[t]{5}{*}{24} & その他 & 0.4 & 4. 4 & 1.7 & 0 & 0 & 1.1 & 1.7 & 4.6 & 0 & 0.8 & 2. 5 & 3. 2 \\
\hline & なし & 0 & 0 & 0 & 0 & 0 & 0 & 1.7 & 0 & 3.6 & 1.6 & 2.5 & 1.9 \\
\hline & 無答 & 0.9 & 4. 3 & 9.9 & 11.1 & 22.7 & 5.1 & 0.9 & 0.8 & 3.6 & 1.6 & 0 & 1.3 \\
\hline & $?$ & 0 & 2. 2 & 1. 2 & 0 & 1.3 & 1.3 & 0.9 & 3.0 & 0 & 0.8 & 0 & 0 \\
\hline & 総 & 108 & 93 & 81 & 90 & 75 & 78 & 117 & 132 & 84 & 129 & 159 & 159 \\
\hline
\end{tabular}

15. 汽船・ボート等。

16. 2. 汽車・電車等も含を。

19. [動物]馬・犬・鳥等。
20.〔植物】木・草花等。

21.「たべもの」・米・チョコレート等。

22. 魔法の杖・忍術の巻物等。 


\begin{tabular}{|c|c|c|c|c|c|c|c|c|c|c|c|c|c|c|c|c|c|c|c|}
\hline & 通 & 地 & & & & & 吅 & 島 地 & 区 & 宮城 & & & 都 & & & & 全 & & \\
\hline 小 & F & 小学 & 6 年 & 中学 & 2 年 & 小学 & 4 年 & 小学 & 6 年 & 中学 & 2 年 & $\begin{array}{l}\text { 東 } \\
\text { 小学 }\end{array}$ & 4 京 & $\begin{array}{l}\text { 仙 } \\
\text { 小学 }\end{array}$ & 4台 & $\begin{array}{l}\text { 東 } \\
\text { 小学 }\end{array}$ & 6 京 & $\begin{array}{l}\text { 仙 } \\
\text { 中学 } 2\end{array}$ & 2 枲 \\
\hline 女 & 男 & 女 & 男 & 女 & 男 & 女 & 男 & 女 & 男 & 女 & 男 & 女 & 男 & 女 & 男 & 女 & 男 & 女 & 男 \\
\hline 2.5 & 0 & 2.6 & 0 & 0 & 0 & 2. 3 & 0.9 & 10.1 & 4. 1 & 11.1 & 1.7 & 2.8 & 1.6 & 1.3 & 0 & 1.2 & 2,6 & 1. 1 & 1.7 \\
\hline 6.2 & 6.7 & 3. 8 & 1.4 & 0 & 0 & 12.1 & 7.2 & 3. 6 & 2. 0 & 1 & 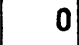 & 0 & 0 & 0) & 0 & 1.2 & 0 & 0 & 0 \\
\hline 4. 9 & 4. 4 & 6.4 & 8. 7 & 0 & 1. 4 & 12.1 & 14. 4 & 10.1 & 5.5 & 8. 0 & 10.0 & 5.6 & $\therefore 1$ & 5.3 & 0 & 4.7 & 1,3 & 1. 1 & 5.0 \\
\hline 11.1 & 0 & 3. 8 & 2. 9 & 6.1 & 8. 3 & 6.8 & 3.6 & 17.5 & 8. 2 & 4.8 & 3.3 & 0.9 & 2. 3. & 0 & 6.0 & 11.9 & 0 & 5.4 & 10.0 \\
\hline 29.6 & 2. 2 & 33.4 & 15.9 & 18. 2 & 5.6 & 5.0 & 9.5 & 2.7 & 12.6 & 2.7 & 6.8 & 9.3 & 2.3 & 13.4 & 3.6 & 11.9 & 2.6 & 49.5 & 0 \\
\hline 6.2 & 4. 4 & .5 & 2. 9 & 0 & 2. 8 & 7.6 & 2. 7 & 6.3 & 2.7 & 1.6 & 0 & 8. 3 & 1.6 & 14. 7 & 2. 4 & 8. 4 & 1.3 & 18. 3 & 0 \\
\hline 0 & 0 & 이 & 0 & 3.0 & 8. 3 & 0.8 & 0.9 & 0 & 5.5 & 8. 0 & 1.7 & 7.4 & 3. 9 & 5.3 & 1. 2 & 9.5 & 9.0 & 2. 2 & 0 \\
\hline 2.5 & 6.7 & 5.1 & 8.7 & 6. 1 & 5.6 & 6.8 & 6.3 & 6.3 & 6.8 & 8. 0 & 6.7 & 6.5 & 9.3 & 2.7 & 7.2 & 4.8 & 6.4 & 1. 1 & 0 \\
\hline 0 & 0 & 0 & 1.4 & 0 & 1.4 & 0 & 0 & c & 0 & 0 & 0 & 0 & 0.8 & 0 & 0 & 0 & 0 & 0 & 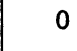 \\
\hline 1. 2 & 2. 2 & 3 & 1. 4 & 0 & 0 & 6 & . & $c$ & 0 & 1.6 & 0 & 0 & & 0 & 0 & 0 & & 0 & 0 \\
\hline 2.5 & 0 & 0 & 0 & 0 & 0 & 0 & 0 & 0 & 0 & 0 & 0 & 2. 8 & 0.8 & 0 & 2. 4 & 0 & 3. 9 & 0 & 21.6 \\
\hline 1.2 & 0 & 0 & 0 & 0 & 0 & 3. 0 & 0 & 1.8 & 0 & 0 & 0 & 4.6 & 0 & 8. 0 & 0 & 2. 4 & 0 & 3. 2 & 0 \\
\hline 0 & 0 & 0 & 1. 4 & 0 & 1. 4 & 0 & 7. 2 & 0 & 8. 2 & 0 & 1.7 & 0 & 8.5 & 0 & 7. 2 & 0 & 11.5 & 0 & \\
\hline 2.5 & 4. 4 & 0 & 0 & 0 & 2. 8 & 2. 8 & 0.9 & 2. 7 & 1.4 & 1.6 & 1.7 & 0 & 6.2 & 0 & 13. 1 & 0 & 1.3 & 0 & 0 \\
\hline 0 & 0 & 0 & 0 & 0 & 0 & 0 & 0 & 1 & 0 & 0 & 0 & 0.9 & 0.8 & 0 & 0 & 0 & 0 & 0 & ( \\
\hline 2.5 & 0 & 3.8 & 0 & 3. 0 & 1. 4 & 3. 8 & 1.8 & 5.4 & 0.7 & 4.8 & 0 & 8. 3 & 0 & 20.0 & 2.4 & 7. 2 & 0 & 7. 5 & \\
\hline 1. 2 & 2. 2 & 0 & 4. 3 & 0 & 0 & 1.5 & 9. 0 & 4.5 & 8. 8 & 0 & 0 & 0.9 & 0 & 2. 7 & 0 & 1. 2 & 1.3 & 2. 2 & 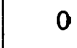 \\
\hline 4. 9 & 0 & 11.5 & 0 & 3. 2 & 0 & 0 & 0 & 1. & 0 & 11.1 & 0 & 0.9 & 0.8 & 5.3 & 0 & 2. 4 & 0 & 4. 3 & 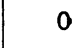 \\
\hline 0 & 0 & 0 & 0 & 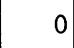 & 0 & 0 & 1.6 & 4 & 0 & 0 & 0 & 0 & 0 & 1.3 & 0 & 1. 2 & & 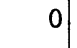 & \\
\hline 2.5 & 4. 4 & 1.3 & 0 & 6. 1 & 4. 2 & 0.8 & 0.9 & 0.9 & 0.7 & 0 & 6.7 & 0.9 & 0.8 & 0 & 0 & 0 & 2.6 & 0 & 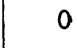 \\
\hline 0 & 0 & 0 & 1.4 & 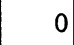 & 0 & 0 & 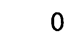 & 4. 5 & 6.8 & 4. 8 & 0 & 11.1 & 7. 8 & 0 & 0 & 0 & 1.3 & 이 & 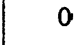 \\
\hline 1. 2 & 2. 2 & 2.6 & 0 & 3. 0 & 1. 4 & 0 & 0 & 0 & 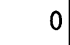 & 0 & 0 & 0 & 2. 3 & 7 & 0 & 0 & 2.6 & & \\
\hline 0 & 2. 2 & 0 & 4. 3 & 0 & 0 & 0.8 & 0 & 0 & 6.7 & 1.6 & 5.0 & 0.9 & 3. 1 & 0 & 2. 4 & 0 & 6.4 & 1 & 1.7 \\
\hline 0 & 0 & 2.6 & 1.4 & 0 & 0 & 0 & 0.9 & 0 & 6.7 & 0 & 1.7 & 3.7 & 1.6 & 0 & 0 & 1. 2 & 2.6 & 1.1 & 10. \\
\hline 0 & 6.7 & 2.6 & 2. 9 & 0 & 4. 2 & 0 & 2. 7 & 0 & 6.8 & 0 & 10.0 & 0 & 0 & 1 & 0 & 0 & 1.3 & 1 & 1.7 \\
\hline 0 & 2. 2 & 0 & 2. 9 & 15.1 & 11.1 & 1.5 & 5.4 & 9 & 2.7 & 0 & 6.7 & 5.6 & 9.3 & 10.7 & 26.2 & 4. 8 & 0 & 3. 2 & 10.0 \\
\hline 2.5 & 13. 3 & 0 & 11.6 & 3. 0 & 13. 9 & 0.8 & 3. 6 & 9 & 6.1 & 1.6 & 6.7 & 4. 6 & 10.1 & 0 & 10.7 & 1. 2 & 7. 7 & 0 & 28. 2 \\
\hline o) & 4. 4 & 0 & 5.8 & 0 & 1. 4 & 0 & 3.6 & 2. 7 & 1.4 & 0 & 5.0 & 0 & 3. 9 & 0 & 10.7 & 0 & 10.3 & 0 & 6.7 \\
\hline 1.2 & 2. 2 & 0 & 0 & 0 & 4. 2 & 0 & 0 & 1 & 0 & 0 & 0 & 0 & 0 & 0 & 0 & 0 & & 0 & 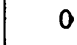 \\
\hline 2. 5 & 6.7 & 0 & 0 & 0 & 0 & 0 & 0.9 & 0 & 1.4 & 0 & 1.7 & 0 & . & 1 & 0 & 1. 2 & & 0 & 1.7 \\
\hline 1. 2 & 0 & 0 & 0 & 0 & 0 & 0 & 0 & 0 & 0 & 0 & 0 & 0.9 & 0 & 1. 3 & of & 0 & 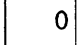 & & \\
\hline 21.0 & 22. 1 & 6.4 & 0 & 6.1 & 5.6 & 12.1 & 6.3 & 2.7 & 4. 1 & 1.6 & 1.7 & 0 & 6.2 & 0 & 0 & 4. 8 & 2. 6 & 0 & c \\
\hline 0 & 0 & 0 & 0 & 0 & 0 & 1.5 & 5.4 & 0 & 0.7 & 0 & 0 & 0 & 0.8 & 0 & 0 & 0 & 1.3 & 0 & 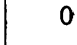 \\
\hline 0 & 0 & 0 & 0 & 0 & 0 & 0 & 0 & 0 & 0 & 0 & 0 & 0 & 0 & 0 & 0 & 2. 4 & 0 & 0 & \\
\hline 4. 9 & & 2.6 & 11.6 & 9.1 & 4. 2 & 1.3 & 0 & 11.9 & 0 & 25.9 & 19.8 & 3.7 & 5.4 & 1.3 & -1.2 & 13.1 & 7. 7 & 0 & 1.7 \\
\hline 0 & 0 & 0 & 0 & 0 & 0 & 0 & 0 & 0 & 0 & 0 & 0 & 0 & 0 & 0 & 0 & 0 & 0 & 0 & \\
\hline 2.5 & 0 & 0 & 0 & 0 & 2. 8 & 2. 2 & 4. 6 & 2. 7 & 0.7 & 1.6 & 0 & 8. 3 & 7.0 & 6.7 & 3.6 & 3.6 & 0 & 0 & \\
\hline 0 & 0 & 0 & 0 & 0 & 0 & 0 & 1.8 & 0 & 8.3 & 0 & 1.7 & 0.9 & 0 & 0 & 이 & 0 & 1.3 & 0 & \\
\hline 81 & 45 & 78 & 69 & 33 & 72 & 132 & 111 & 111 & 147 & 63 & 60 & 108 & 129 & 75 & 84 & 84 & 78 & 93 & 00 \\
\hline
\end{tabular}

23.〔精神や能力】カ・やさしい心等。

24. [兴の他] 他の項に入らないもので，比較的まれ げた。

に出て来るものは，すべてここに一括して実数のみを挙が入り，

〔なし〕の項目には「ありません」・「ない」という答 
Table 6

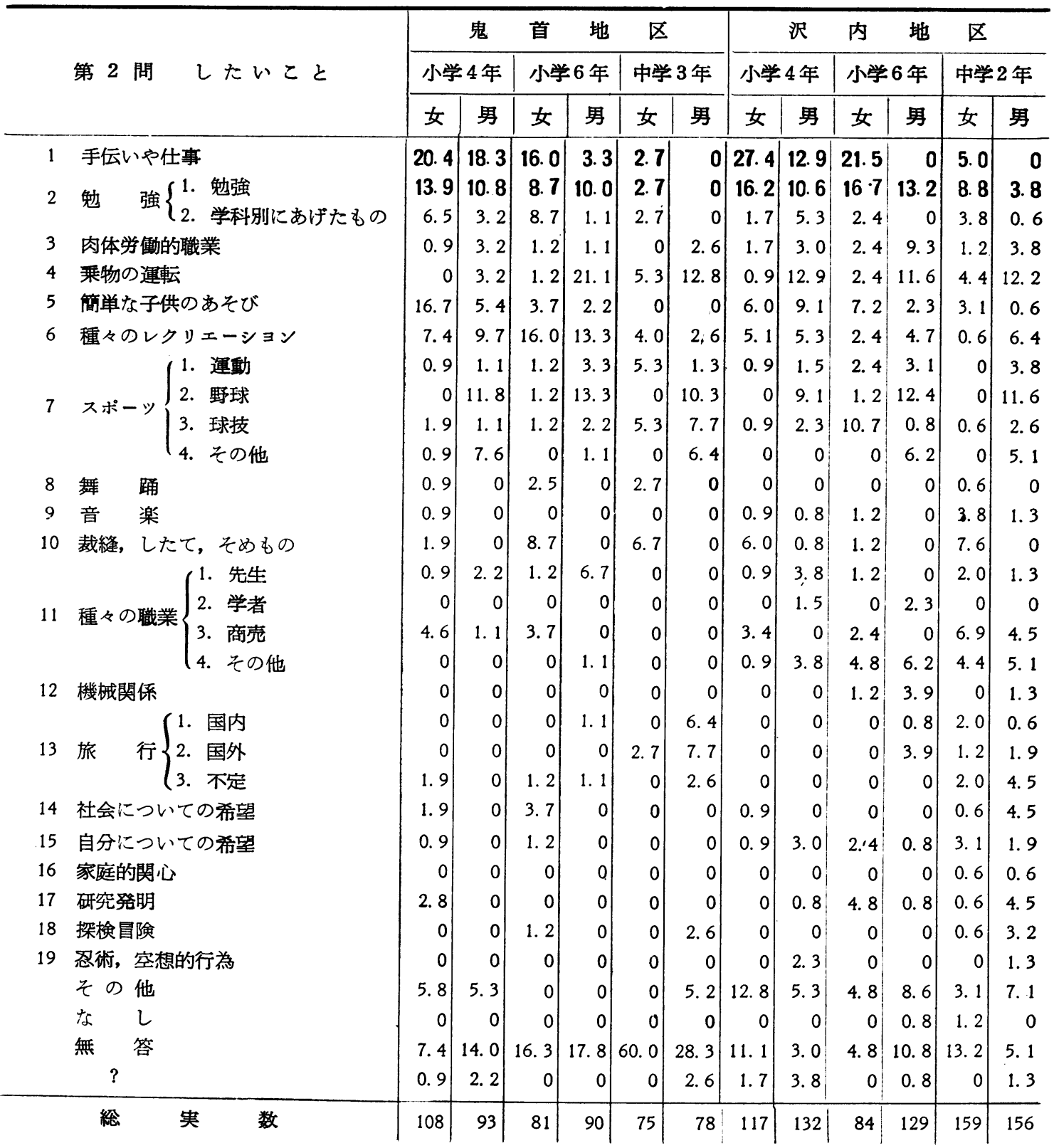

〔無答】は回答がなかつたことを示す。大体 2 番目や 3 番目が書いてないものである。

〔?]は判続できなかつた答。多くは知能の低い者に 見られる。

第 2 閣 (したいこと) 一Table 6

1.〔手伝いや仕事「てつだい」・「うちのしごと」・ 庭惊きるるすばん・子守り・御飯たき・水くみ・田かき ・たき木しよい等の答。
2. 1. 単に「勉強」と答えたもの。

2. 2. 国語・社会・理科等と答えたもの。

3. [肉体労働的職業]土方・百性・りょうし(漁夫) 等。

4.〔乗物の運転】自転車から飛行機まで含む。

5.なわとび・かくれんぼ等。

6. 運動会・遠足・花造り・トランプ等種類が多い。

7. 4. の中に㰸道・柔道が入つている。 


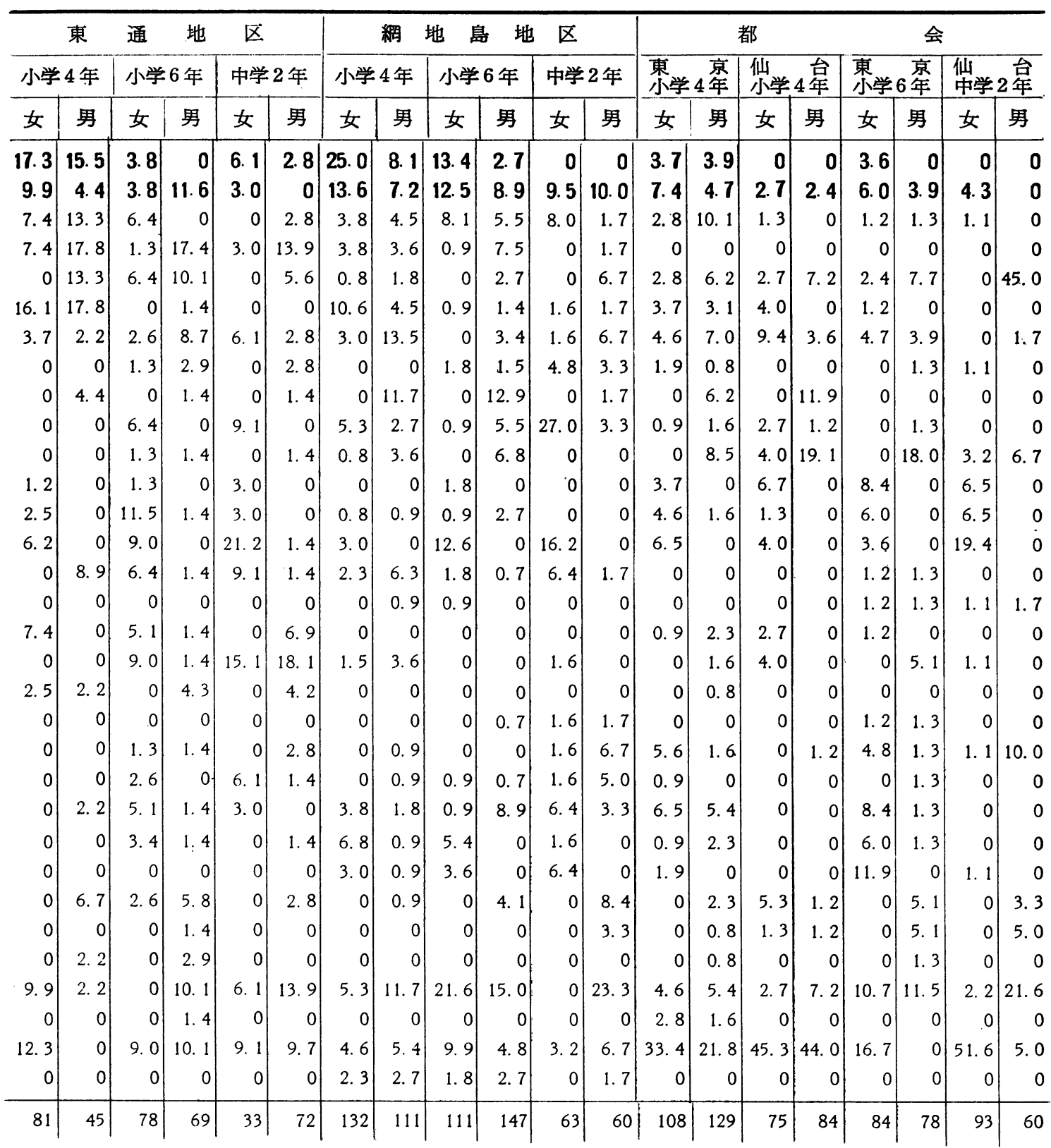

12.〔機械関俰〕生産機械・計測機械等を扱うこと。

14. 〔社会についての希望】戦争をなくすこと・学校 をよくすること等。

15.〔自分についての希望】えらくなること・字が上 手になること等。

16. 〔家庭的関心〕姆を楽!こしたい」というもの等。 第 3 問 (なりたいもの) 一Table 7

1. 次りたいものの所入更:水く州・庭はき等之答え
たもの。第 2 問に「御飯たきをしたい」と答えこここで 「御飯たきになりたい」と答えている様なものもある。 6. [商売屋]「おみせや」・菓子屋・雑貨屋等。

7. [交化的職業]は, 映画監督・ラジオ屋・アナウ ンサー等。

10.には社長も社員も入れた。

これらの分類項目におさめた後，実数を百分率になお 寸。例えば鬼首, 小学 4 年，女は 1 問につい:回答の綕 
Table 7

\begin{tabular}{|c|c|c|c|c|c|c|c|c|c|c|c|c|c|}
\hline & \multirow{3}{*}{ 第 3 問 なりたいもの } & & 鬼 & 首 & 地 & \multicolumn{2}{|l|}{ 区 } & \multicolumn{2}{|r|}{ 沢 } & 内 & 地 & \multicolumn{2}{|l|}{ 区 } \\
\hline & & \multicolumn{2}{|c|}{ 小学 4 年 } & \multicolumn{2}{|c|}{ 小学 6 年 } & \multicolumn{2}{|c|}{ 中学 3年 } & \multicolumn{2}{|c|}{ 小学 4年 } & \multicolumn{2}{|c|}{ 小学 6 年 } & \multicolumn{2}{|c|}{ 中学 2 年 } \\
\hline & & 女 & 男 & 女 & 男 & 女 & 男 & 女 & 男 & 女 & 男 & 女 & 男 \\
\hline 1 & 2 問:䑙りる「手伝いや仕事」の反復 & 14.8 & 3. 2 & 1. 2 & 이 & 1.3 & 0 & 4.3 & 0 & 0 & 0.8 & 0 & 0 \\
\hline 2 & 2 問における「勉強」の反復 & 5.6 & 0 & 1. 2 & 0 & 1.3 & 0 & 5.1 & 0 & 0 & 0 & 0 & 0 \\
\hline 3 & その他 2 問に入れるべき答 & 0 & 2. 2 & 2.5 & 0 & 0 & 0 & 9.4 & 10.6 & 1.2 & 0.8 & 0 & 3.8 \\
\hline \multirow[t]{2}{*}{4} & 1 問:入れれるべき答 & 1.8 & 4. 3 & 1.4 & 1.1 & 0 & 0 & 6.9 & 3.0 & 2. 4 & 0 & 0 & 0.6 \\
\hline & (1. 大工 & 0.9 & 4. 3 & 0 & 5.6 & 0 & 0 & 0.9 & 4.6 & 0 & $2: 3$ & 0 & 6.4 \\
\hline \multirow[t]{2}{*}{5} & 肉体労動的職業 $\{2$. 農業 & 2. 8 & 4.3 & 3.7 & 1.1 & 0 & 0 & 3.4 & 3. 0 & 13. 1 & 2.3 & 1.2 & 4.5 \\
\hline & (3. その他 & 0.9 & 3. 2 & 0 & 67 & 0 & 1.3 & 0.9 & 3. 8 & 0 & 1.6 & 0 & 0.1 \\
\hline 6 & 商売屋 & 4.6 & 7.6 & 4. 9 & 0 & 0 & 3.9 & 7.7 & 2.3 & 9.5 & 7.0 & 6.3 & 3.8 \\
\hline 7 & 交化的職業 & 0 & 0 & 1. 2 & 1.1 & 1.3 & 0 & 0 & 0.8 & 0 & 6.2 & 1. 2 & 7. 1 \\
\hline 8 & 政治 家 & 0 & 0 & 1. 2 & 1.1 & 0 & 3. 9 & 0 & 0 & 0 & 0 & 0 & 0.6 \\
\hline 9 & 船の職業 & 0 & 0 & 0 & 3. 3 & 0 & 2.5 & 0 & 0.8 & 0 & 0.8 & 0 & 1.9 \\
\hline 10 & 勤的人, 会社関係 & 1.9 & 0 & 1. 2 & 33 & 0 & 3.6 & 0 & 0 & 1.2 & 2. 3 & 2.5 & 9.0 \\
\hline \multirow[t]{2}{*}{11} & 技術 者 & 0 & 0 & 0 & 0 & 0 & 0 & 0 & 0 & 0 & 1.6 & 0 & 3.8 \\
\hline & (1. 校長 & 0.9 & 0 & 0 & 1.1 & 0 & 0 & 0 & 0 & 0 & 0 & 0 & 0.6 \\
\hline \multirow{3}{*}{12} & 学校閏係 2 . 先生 & 10.0 & 8.6 & 9.9 & 7.8 & 2.7 & 2.6 & 13.7 & 13.7 & 14.3 & 10.9 & 6.3 & 5.1 \\
\hline & 子枚成休 3 . 役員 & 0.9 & 0 & 0 & 0 & 0 & 0 & 0 & 0.8 & 0 & 0 & 0 & 0.6 \\
\hline & l'4. 上級学生 & 1.9 & 0 & 0 & 0 & 0 & 0 & 0.9 & 4. 6 & 1. 2 & 0.8 & 2. 0 & 0 \\
\hline 13 & 学者研究家 & 0 & 0 & 0 & 0 & 0 & 0 & 0 & 3. 0 & 4. 8 & 7. 0 & 5.0 & 5. 1 \\
\hline 14 & 医 & 0.9 & 1. 1 & 0 & 1.1 & 0 & 0 & 0 & 0.8 & 0 & 4. 7 & 0 & 0.6 \\
\hline 15 & 運転関係 & 0.9 & 14. 0 & 0 & 8. 9 & 0 & 10.3 & 7.7 & 13.7 & 14.3 & 14.7 & 6.3 & 12. 8 \\
\hline 16 & スポーツ選手 & 0 & 3. 2 & 14. 8 & 5.6 & 0 & 3.9 & 0.9 & 7.6 & 1. 2 & 10.8 & 0 & 19. 2 \\
\hline 17 & 婦人職業 & 6.5 & 0 & 3. 7 & 0 & 29.4 & 0 & 15.4 & 0 & 13. 1 & 0 & 31.0 & 0 \\
\hline 18 & 芸術芸能関係 & 0.9 & 0 & 4. 9 & 1. 1 & 2.6 & 0 & 3.4 & 0.8 & 4. 8 & 0 & 12.6 & 3. 8 \\
\hline 19 & 金 持 & 0 & 0 & 7.4 & 0 & 0 & 0 & 0 & 0 & 0 & 0.8 & 0.6 & 0 \\
\hline 20 & 自己の向上 & 0.9 & 1. 1 & 1.2 & 2. 2 & 1.3 & 0 & 0.9 & 1.5 & 6.0 & 4. 7 & 5.0 & 1.3 \\
\hline 21 & 天皇, 王様等 & 0 & 0 & 1.2 & 1. 1 & 0 & 0 & 0 & 0 & 0 & 0 & 0.6 & 0 \\
\hline 22 & 動物, 植物 & 0 & 0 & 0 & 2. 2 & 0 & 0 & 0 & 2. 3 & 0 & 0 & 0 & 0.6 \\
\hline 23 & 魔法 使 & 0 & 0 & 0 & 0 & 0 & 3.9 & 0 & 2. 3 & 0 & 1.6 & 0 & 0 \\
\hline \multirow[t]{6}{*}{24} & 兵隊, 警官 & 0 & 6.5 & 1. 2 & 2. 2 & 0 & 0 & 0 & 5.3 & 0 & 1.6 & 0 & 0 \\
\hline & この他 & 14.8 & 4. 3 & 2. 9 & 6.7 & 1.3 & 22.0 & 4. 3 & 3. 8 & 4. 8 & 0.8 & 6.9 & 4.5 \\
\hline & 栾 & 0 & 0 & 0 & 0 & 0 & 0 & 이 & 0 & 0 & 0 & 0.6 & 0 \\
\hline & 無 & 21.3 & 31.2 & 32.1 & 33.3 & 58.6 & 40.0 & 14.5 & 11.4 & 8. 4 & 13.9 & 12.6 & 1.9 \\
\hline & $?$ & 6.5 & 1.1 & 0 & 3.3 & 0 & 2.6 & 0 & 0 & 0 & 0 & 0 & 0 \\
\hline & INA & 08 & 93 & 81 & 90 & 75 & 78 & 117 & 132 & 84 & 129 & 159 & 156 \\
\hline
\end{tabular}

数が 108 個(人数はその厉である)であつたので，108を ベースにした百分率である。これは全く表を見易くする ための措置である。

なお，東京と仙台の学校から得た結果を比較のために 並べたが，調查校は東京都四谷第六小学校・仙台市八幡 小学校及び東仙台中学校であつて, 都会のごく普通の学 校である。

\section{b 㑭人别の類㗏からの分類}

Table 5. 6. 7 においては, 例えば 2 問の 1 「手伝い や仕事」の答が何\%あつたか解るが，1 1 人の子供につ いての 3つの答が全部手伝いや仕事である場合と，1つ だけが手伝いや仕事で，あとは別種の答をしている場合 との違いをぬりつぶしている。当然 1 人 1 人について内 容を検討した結果をまとめなければならない。 


\begin{tabular}{|c|c|c|c|c|c|c|c|c|c|c|c|c|c|c|c|c|c|c|c|}
\hline & & 角 & & & & & 網 & 地 & 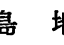 & & & & & 都 & & & 会 & & \\
\hline 小学 & 4 年 & 小学 & 年 & 中学 & 2 年 & 小学 & 4 年 & 小学 & 6 年 & 中学 & 年 & 東 & $\begin{array}{l}\text { 京 } \\
\text { 年 }\end{array}$ & 仙 & & 東 & 6京 & 仙 & \\
\hline 女 & 男 & 女 & 男 & 女 & 男 & 女 & 男 & 女 & 男 & 女 & 男 & 女 & 男 & 女 & 男 & 女 & 男 & 女 & 男 \\
\hline 3. 7 & 2. & & & & & .4 & 3. & & 1. & & & & & & & 0 & & 0 & \\
\hline 0 & 0 & 1.3 & 1.4 & $c$ & c & 4.6 & 3. & 6.4 & 11.6 & 1.6 & 1.7 & 0 & & & 0 & 0 & 0 & 0 & C \\
\hline 2. 3 & 0 & 1. 3 & 2. 9 & c & 1.4 & 3. & 4.5 & 5.5 & 6.8 & 1.6 & & 4. 6 & 0.8 & & 0 & 0 & 0 & 0 & 0 \\
\hline 3.7 & 4. 4 & 3 & 1.4 & $c$ & 1.4 & 3.0 & 3.6 & & 0 & 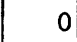 & & 0.9 & 3. & & 0 & 0 & 0 & 3. 2 & \\
\hline 0 & 4. 4 & 0 & 4. & c & 4. 2 & 0 & 1. & 0 & 0.7 & 0 & 1. 7 & 0 & 1.6 & & 0 & 0 & 0 & 0 & $c$ \\
\hline 1. 2 & 0 & 0 & 1.4 & 3.0 & 4.2 & 3 & 0.9 & 0 & 0 & 0 & & & & & 0 & 0 & 0 & 0 & 0 \\
\hline 0 & 11.1 & 0 & 1 & 0 & 11. & 0 & 14.4 & 0 & 11.7 & 0 & 3. 3 & 0 & 0 & & 0 & 0 & & 0 & \\
\hline 1. 1 & 2. 2 & 5. 1 & 0 & 1 & 3 & 3. 8 & 8 & 0.9 & 0 & 0 & 0 & 3.7 & 4. 7 & 1.3 & 1.2 & 3.6 & 2.6 & 0 & 0 \\
\hline 0 & 0 & 0 & 2. 9 & 9.1 & 2. $\varepsilon$ & 0 & 0.9 & 0 & 0 & 0 & 1.7 & 0 & 3. 1 & 5. 3 & 1. 2 & 0 & 1. 3 & 3. 2 & 5.0 \\
\hline 0 & 2. 2 & 0 & 1. & 0 & 0 & 0 & 0 & 0 & 2. 0 & 0 & 5. & & 1.6 & 0 & 4. 8 & 1. 2 & 3. & 0 & 31. \\
\hline 0 & 2. 2 & 0 & 2. 9 & 6.1 & 13.5 & 0 & 0 & 0 & 0 & 1.6 & & & 0.8 & 0 & 4. 8 & 0 & 1. & 0 & 16.7 \\
\hline 1. 2 & 2. & 0 & 1. & & 5.6 & 0 & 0 & 0.9 & 1.4 & 3. 2 & 5.0 & 0.9 & 3. 1 & 0 & 0 & 4. 8 & 12.7 & 5.4 & 8. 3 \\
\hline 0 & $c$ & & & & & 0 & 0 & & 0 & & & & & & 0 & 0 & 2.6 & & 0 \\
\hline 0 & 0 & 0 & 0 & c & c & 0 & 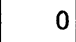 & 0 & 0.7 & 0 & 0 & 0.9 & 3. 9 & 0 & 1. 2 & 1. 2 & & & \\
\hline 4.8 & .5 & 1 & 5 & 2 & 6.5 & 1 & 3.6 & 10.9 & 3. 4 & 4. 8 & 6.7 & 16.7 & 4. 7 & 18.7 & 4. 8 & 9.6 & 3.9 & 7.5 & $c$ \\
\hline 0 & 0 & 0 & 0 & & & 0 & 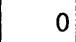 & & 0. & & & 0 & 2. 3 & 1.3 & 1. 2 & 0 & 1.3 & 0 & ( \\
\hline 1. 2 & 0 & 0 & 0 & 0 & 4 & 0 & 0 & 0 & 0. & 0 & & 0 & 0 & & . & 0 & 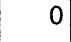 & & 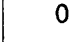 \\
\hline 0 & 0 & 0 & 7. 2 & $c$ & 4 & 0 & 6.4 & 0 & 4. 6 & 1.8 & 3. 0 & 1.9 & 2. 3 & 1.3 & 0 & 2. 4 & 11.5 & 10.8 & 13.3 \\
\hline 0 & 8. 9 & 0 & 4.3 & 6. 1 & 5.6 & & 1.8 & 0 & 0 & 1. & & 1.9 & 1. & & 0 & 1. 2 & 2.6 & 0 & 0 \\
\hline 2. 5 & 5 & 8 & 6 & 12. & 1 & 0 & 2. 7 & 0 & 9.6 & 0 & 5.0 & 0 & 9.3 & 2.7 & 11.9 & 0 & 12.7 & & c \\
\hline 2.5 & 8. 9 & & 8.7 & & 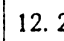 & 0 & 6. 3 & 0 & 4. 1 & 0 & 5. 0 & 0.9 & 21.8 & 0 & 20. 2 & 0 & 18. 0 & 4. 3 & 5.0 \\
\hline 4. 1 & 1 & & 4 & 2 & 1.4 & 11.4 & 0 & 15.4 & 0 & 22. 2 & $v$ & 4. & 0 & 1.3 & 0 & 4. 8 & 0 & 2. & 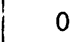 \\
\hline 0 & 0 & & 9 & & $c$ & 2. 2 & 1.8 & & 0.6 & 4. 7 & 0 & 19.4 & 3. 1 & 6.7 & 0 & 16.7 & 1.3 & 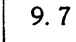 & ( \\
\hline 0 & 0 & & 0 & & & & 0. & & 0. & & 0 & 0.5 & U & 2. 7 & 0 & 0 & 0 & 1.1 & 3. 3 \\
\hline 6. 2 & 2. 2 & 6 & 4 & c & $c$ & 9 & 2. 7 & 12.7 & 6.1 & 7. 9 & 1.7 & 6.5 & 1.6 & 16.0 & 4. 8 & 16.7 & 2. 6 & 1. 1 & \\
\hline 0 & 0 & 0 & 0 & c & c & 15.0 & 3. & 0 & 0.6 & 5 & 1.6 & 1.9 & 1.6 & 0 & 1. 2 & 0 & 1. & & 1.7 \\
\hline 3. 7 & 0 & 0 & 0 & 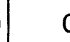 & & & 6. & & & & & 0 & 2. 3 & 0 & 0 & 0 & 2. 6 & & c \\
\hline 0 & 0 & 0 & 0 & c & $c$ & 0 & 2. & 0 & 0 & 0 & 0 & 9 & 0.8 & 0 & 4. 8 & 1. 2 & 3. & 0 & 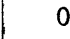 \\
\hline 0 & 4. 4 & 1.3 & 1.4 & c & 1. & 0 & 8 & 0 & 0.6 & 0 & 0 & 0.9 & 5.4 & 0 & 3. 6 & 0 & 1. 3 & 0 & 5.0 \\
\hline 5 & 0 & & 1.4 & & & 4. 6 & 2 & 9.4 & 8. 2 & 23. 8 & 18.3 & 4. 6 & 4. 7 & 2. 7 & 10.7 & 9.5 & 7.7 & 5.4 & 10.0 \\
\hline 0 & 0 & 0 & 1.4 & 6. & $C$ & 0 & 0 & 0 & 0 & 0 & 0 & 6.5 & 1.6 & 0 & 0 & 0 & 0 & $n$ & 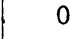 \\
\hline 13. 6 & 13.3 & 10.3 & 7. 2 & 18.2 & 8.3 & 12.1 & 5.4 & 15.3 & 7.5 & 15.9 & 0 & 20.4 & 14.7 & 40.0 & 29.8 & 27.4 & 5.1 & 46.3 & 0 \\
\hline 2. 5 & 13.3 & 1.3 & 4. 3 & 3. & 1. & 0 & 3.6 & 2.7 & 1.4 & 1.6 & 6.7 & 0 & 0 & 0 & 0 & 0 & 0 & 0 & 0 \\
\hline & & & 69 & נo & 72 & 132 & 111 & $A$ & 147 & (5) & 60 & 108 & 129 & 75 & 84 & 84 & 78 & 93 & 60 \\
\hline
\end{tabular}

そこデ，次の 4 つの指標を選んで，それに当てはまる

者が，地区別・学年别 - 男女别に何人いるかを示すと

Table 8 の如くになる。

イ「「にいもの」が主として1 間 1．2．の「鉛筆・

けしごむ・帳面の類」の項に入る答であり，「した いこレ」が主として 2 問 1 の「手伝いや仕事」の項 に入る答であるもの。
ロ）「したいこと」が主として手伝いや仕事で占めら れていて他には別に特徴のないもの。

八）「ほしいもの」が主として鉛筆・けしごむ・帳面 の類であり，他には別に特徴のないもの。

二) その他, 定型的ではないが, 以上の特徽が混じつ ていたり， 3 問において 1 問 2 問に対する答えの反 復があつたりしたもの。 


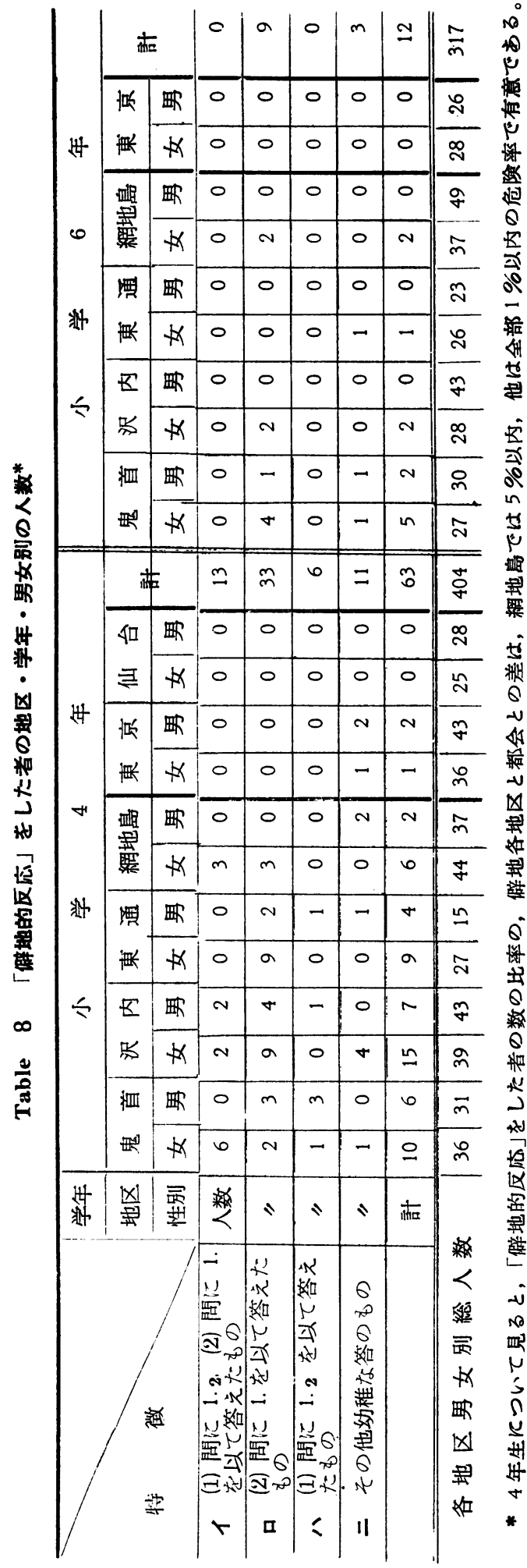

これらの反応を我々は後に述べる様な理由により表で は仮に「僻地的反広」と呼んで置く。

この様な反応型と学校の成績との関係は, 沢内地区の 新町・川舟の両部落, 東通地区の入口部落において調べ てあるのでそれを示すと Table 9 つ様になる。この場合 の学業成績上・中・下は担当教師の判定による。

Table 9 「僻地的反応」をした者の 学業成綾别人数 （沢内地区及び東通地区の入口部落）

\begin{tabular}{c|r|r|r|r}
\hline 成績 & \multicolumn{1}{|c|}{ 上 } & \multicolumn{1}{|c|}{ 中 } & \multicolumn{1}{|c|}{ 下 } & 計 \\
\hline 男 & 1 & 6 & 4 & 11 \\
女 & 2 & 10 & 7 & 19 \\
\hline 計 & 3 & 16 & 11 & 30
\end{tabular}

（B） 要求調查 $B$ 票を加えた場合

1 我々の調査の関心は, 要求の対象そのものを問題 にするだけではなく，更に子供達が自分の要求を考光， 発表する過程を考察することにあることは前に述べたが Table 8 に示された様な子供達は，各問に対する答の色 色なケースを教えてやれば，異つた反応をするであろう か。このことを見るべく，東通地区と沢内地区とでは， 4 年生を対象として, 次の 手続きによつて調查を行つ た。

2 要求調查 ( $\mathrm{A}$ 票)を行うた翌日, ほしいもの・し たいこと・なりたいもの，の回答例を色々並べて印刷し てある B票を各人に配り，「よその学校の抢友達の答の 中にはこんなものがありました。一緒に読んで見ましよ う。わからないものにはメをつけて下さい」と云つて, ゆつくり読みながら一々吟味させた。B票に挙げられて いるものは，それまでの調查で得られた僻村での答も都 会での答も合わせて検討し，その中から適当に選んで並 ベたものであつて，内容はTable 10の如くである。B票 を回収した後，続いて更にA票を配り，もう一度考えて もらつて答を畫かせた。

3 要求調查 ( $\mathrm{A}$ 票) の第 1 回目と第 2 回目とで答が どう変つたかについて，次の範囲内で結果をまとめた。

Table 8 における 4 つの指標のどれかをもつ者につい てのみ変化を調べた。

変化の分類は, Table 8 の指標となつた種類の答が, 第2 回目において,

1）無くなつた者

2）減少した者

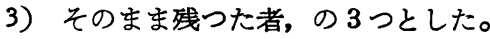

この場合学業成績との関係を見るため, 成績を上・中 
-下 (担任教師の判定による)に分けて沢内地区の分を 示すと Table 11 の様になる。

Table 10

要 求 調 查 $B$

(1) えんぴつゃ帳面。色々な本。ば5しゃかばん。 きものやよらふく。机や本箱。家や部屋。扣金。ま クやをはじき。野球やベレ一の道具。ピアノやオル ガンやハーモニカ。食べ物。さいほ5の道具。シジ オ。テレビジョン。カメラ。双眼鏡。映写機（映画 をらつすをかい）。幻燈機。汽船やボート。汽車や 自動車。飛行機。ジェット機。ヘリコプター。忍術 やまほう。

（2）手つだいや仕事。勉強。かくれん洼や打てだ ま。野球やバレーボール。自動車や汽車の運転。飛 行機のそうじゅう。運動会や遠足。扣どり。音楽。 さいほう。いけ济な。日本めぐり。外国めぐり。発 明。探検。冒険。

(3) 扔みせやさん。大工。扣百婎。汽車や自動車 の運転手。床屋や美容師。医者。かんでふ。議員や 大臣。先生。学者。船の船長やきかんし。スポーツ 選手。アナウンサー。映画はいゆ5。音楽家。画か き。王子様や王女様。まほう使い。

（漢字にはすへてかなを付けてあり，また一通り読 んできかせた）

Table 11

要求調查をB票を加えて 2 回行つた時の「餢地 反応」的特徴の变化と学業成絃との関係 (沢内地区)*

\begin{tabular}{|c|c|c|c|c|}
\hline 成績 & 特 徵 の 消 長 & 男 & 女 & 計 \\
\hline \multirow{3}{*}{ 上 } & 無く叔つたもの & 0 & 0 & 0 \\
\hline & 減少したもの & 0 & 0 & 0 \\
\hline & ヒののま残つたもの & 1 & 1 & 2 \\
\hline \multirow{3}{*}{ 中 } & 無くなつたもの & 3 & 3 & 6 \\
\hline & 淢少したもの & 0 & 3 & 3 \\
\hline & そのまま残つたもの & 1 & 2 & 3 \\
\hline \multirow{3}{*}{ 下 } & 無くなつたもの & 0 & 0 & 1 \\
\hline & 減少したもの & 2 & 4 & 6 \\
\hline & そのまま残つたもの & 0 & 2 & 2 \\
\hline
\end{tabular}

*この調查では，B票を回収した後に 2 度目のA票 を渡すのだが，入口部落に扣いては，B票を見せな がら 2 度目のA票に筆答させたので, 条件の均一の ために本表に扣いては沢内地区のみを出してある。

\section{〔3]考察}

以上挙げた結果以外にもまとめるべき資料は残つてい るのであるが，今回は前述の結果について考察を加えて 置く。

（1）先ず一般的な要求調查 (A 票) の結果を Table 5・6・7について概観すると，色々なことに気ゔくの であるが，僻地と都会とを比較して見て目につく傾向の 一部は次の点であろう。

a 第1問〔ほしいもの〕のところで「鉊筆・けしご む・帳面の類」の項の回答が僻地では学年の低い方 に，また男より女に多く見られ，これらは特に鬼首 地区の 4 年生に著しい。この様な反応は都会では極 めて稀である。

b 第2問〔したいこと〕のところで，「手伝いや仕 事」の項の上に同様の傾向が認められる。家の仕事 の手伝い，子守りとか御飯たきとかたき木しよいと かいう様な仕事であるが，これらの反応は僻地を通 じて見られる傾向であつて,やはり学年の低い方に. また男より女に多く認められる。都会にも少しはあ るが僻地との差は一見して明らかである。

c. 同じく第 2 問〔したいこと〕で「勉強」というの が僻地を通じて多く認められる傾向であり，都会流 それ程でない。

$\mathrm{d}$ 第 3 問〔なりたいタの〕のところで，第 2 問〔し たいことうの答，即ち「手伝いや仕事」「勉強」を 反復しているものやその他第 2 問の答に入るべきも のが僻地の学年の低い方に准々認められることであ る。

（2）然らば我々はこの様な事実についてどう考えた らよいであろうか。始め:問題にした様に，我々の「要 求調查」は設問の形式として决，3つの質問共，答を考 えて反応する上にあら沙る自由度を与えているのである が，それが個々の子供達自身の課題として取り上げられ る時には，当然のこととして回答場面のもろもろの規定 条件によつて制約せられて来る。この調查が学校の教室 において行われたことも必ず念頭に置かねばならない が, 子供の側の個体的条件として, 僻地に育ち僻地の学 校に通つている子供達では，僻地の自然的・地理的条件， 文化的条件, 経斉的条件, 教育的条件等に規定せられる 生活の体験が彼等の反応を制約しているであろうことが 考えられる。

前に挙げた「鉊筆・けしごむ・帳面の類」は彼等がふ だん持つており, 用いており, 或いは少くとも身近かに 目撃しているところの特别取り立てて云う程のことも亦 
い品物であり，「手伝いや仕事」は彼等がふだん家で毎 日やつていること，或いは少くとも身近かに目慗してい ることである。それならば先ず前者においてほしいもの に「えんぴつ」や「けしごむ」を畫く子が現実にその様 な品物に不自由しているのであろうか。この種の反応の 最も多かつた鬼首地区*の 4 年生の例でも，担当の教師 に裉ねた結果ではその様なととは認められなかつた。ま た後者の場合, 子守りやたき木しよい等は子供達にとつ て楽しい仕事というよりは，むしろ辛い仕事であるが或 いは他の仕事に比べて望ましいという程度の仕事である と考えられる**。しかし一般の農村に認められる様に子 供達を家族学働力として小学校の低学年時代からしつけ て行く傾向は僻地の山村等において特に著しい。てれは 生産機構の難条件加ら, 主要労働力としての父母達の手 の及ばない労働面を分担せねばならない現実から来る。 そしてての様な山村の子供達は「無感觉のままに肉体労 働に夌加」しているのであつて, 平野村の子供にややる すると見受けられる様な親から与えられる仕事に対する 不满や仕事からの逃避が，山村の子供達には余り見られ ないと云われる***。

つまり，前述の回答に見られる「鉊筆・けしごむ」反 応や「仕事」反応は，僻地の子供達にとつて空間的・心 理的に身近かな経験の再生であり，いわば心理学的な生 活空間****の現実尿において反応しているのである。け だしこれらの反応は仮定に立つものではなく身辺的・習 慣的なむのの反復に過ぎないのであつて，思いめぐらす

*我々の今回の調查地区の中で「僻地」的印象を最 も強く受けたのは鬼首の分校区域であつた。

** 我々の今回の調査では希望する理由を書かせてい ない。ただ子供達がその様な仕事を進んでしたがると いらことは耳にしなかつた。ここで参考になるのは福 尾氏の農山村児童の働きの調查に扣いて得られている 子供達の答えである。いやな仕事，好きな仕事，並び にその理由の調查であるが，そこでは子守りやたき木 しよいは眉が痛くなるからいやだといら答えがある一 方，子守りは遊ぶによいから好き，たき木しよいは途 中で遊べるから好き，といら答えす得られている。福 尾武彥, 村の教育, 社会学講座4, 昭 28, p p 69, 71

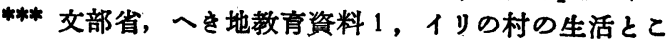
ども一山村社会の形成過程を見つめて一一, 昭29, p. 277

**** K. Lewin Kよって用いられ始めた心理学に指 ける生活空間 (life space) の概念である。生活空間 は現実的水準の領域だけでなく空想や想像の様な概念 的空間としての非現実的水準の領域をも含んでいる。 現実的領域で绀不可能な移動す非現実的領域では可能 である。そして夫々の領域にまた色々な部分領域の分 化があり得る。従つて現実・非現実の两水準の関保は 三次元的に表現せられる。
活動が現実の生活からそれだけ自由でないことを示して いると見られよう。ほしいものやしたいことの希望に限 りなく思いを馳せ，自由にあれこれと考えて見るために は，生活空間の非現実的領域がゆたかに分化していなけ ればならない。「何でも可能としたら」という仮定も， 僻地の子供達の一部においては非現実層からの反応を解 発し得なかつたのであり，この様な事実に反映される限 りにおいての生活空間の未分化性というものが僻地の児 童の心理的特性として把握せられるであろう。そしてて の傾向は高学年に至れば次第に消去せられるが，この特 徽は女子においては男子よりも強くまた高学年まであと を引く傾向が諗められるのである。(この点を見易くす るためにTable 5・6・7 の欄では女を左に揭げてある。)

然らばこの様な未分化性は精神発達の立場から考えれ ばどの様な意味をもつであろうか。従来の研究から見て も, 現実の世界と想像の世界とが一通り分化して来るの は小学 4 年㥧からと考えられよう。例えば牛島氏は 4 ・ 5 年生になると「その視野は広くなり，自分の将来のと とを色々と考える様になる」ことを指摘している*。 我々の調查では, 僻地児童の 4 年生においてはなお未分 化な反応が少くない。このことは，低学年の僻地児童に おいては都会児童, 更には一般の児童に対して精神発達 の面でかなりのずれがあることを示すとも云えよう**。

次にCに挙げた「勉強」をしたいという答が僻地児童 を通じて目立つ点である。彼等のしたいことは「べんき よう」である。しかし，ての「べんきよう」は一般的に 見て大いに学業に精励して成績を上げようというのでは なく，「べんきよう」とはつまり「学校へ行くこと」で あると考えられる。僻地の子供達にとつては学校という あのは楽しい所である。それは知的刺战を受ける勉学の 場であるだけでなく，山村においては簡単に行き来ので きない家々から来る子供達の集まる交友の場であり，ま た僻地児童一般を通じて云えるととは，何よりも先ず家 庭学働から解放された悡いと遊びの場であるということ である***。或る僻地の教師は云う，「町の子供達は授

* 牛島我友, 小学生の心理, 昭27, p.110. そこで 挙げられている资料には次の様な手記 (回想記録) が ある。「この時代の特筆すべきことは，前の時代には あくまで自己の身辺のみの生活に没頭していたが, こ の時代には将来の希望に眴の火を燃やしたのである (以下略)」（女，3・4 年）

**我々の調査した僻地の子供達が都会児童に比へて 知能的発達に扣いて一般に遅れていることはIIの中島 ら報告に示されている。

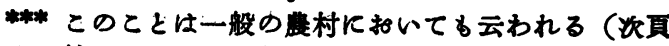
左註*)が，辟地の子供達にとつてい特にそ5である。 
業が済むと嬉々としてサッと引上げろが，ここの子供達 は授業が済んでも仲々家へ帰ろうとし夜い」。このこと は父兄の側からの学校観にも対応寸る。これは教育に無 理解な父兄の声として挙げられている例であるが, 僻地 の或る父兄は云う，「大きなものが学校へ行つて遊んで いる、全く人手不足の農家にとつて惜しいことだ」と**。 教育に対する父兄の無理解一一少く上も無関心一洺 くの僻地校教師の䩭くところであり, その由つて来る歴 史的・地域社会的な事情は存する訳であるが，我々は「学 校」というものが僻地の子供達にとつて意味する機能を 先ず直視せねばなるまい。そしてそれは都会の学校の場 合と余程違う趣きをもつのである。

最後にdに指摘した第 3 問〔なりたいもの〕と第 2 問 〔したいこと〕との混乱であるが，これは内容的関係も あり一応無理からぬ面甩ある。しかし Table 7 が示す 如く,この様なことは都会の子供達においては殆んど見 られなかつた。并の点からしても, これも僻地の子供達 の未分化性の一面它反映するものとも考えられよう。

(3) 以上の様な考察にもとづいて, 我々: $\mathrm{a} \cdot \mathrm{b} \cdot \mathrm{d}$ 即亏生活空間の未分化性を示すものと考只られる反応を 仮に「僻地的反応」と呼えで置くことにした。発達的に は低段階の反応と考えられるものである。

然らば。個々人について見て、この様な反応を特こ特徴 的に示す子供は僻地に沶いてどの程度おり，末た都会で はどうであろうか。前揭の Table 8 がそれを示す。明 らかにその様な子供は僻地こ多い。僻地の各地区***之 都会との間には有意の差が認以られる。

次にこの様な反応を特徴的に示す子供達は学業成績の 面ではどうであろうか。Table 9 がそれ亦す。一応予 想せられる様に成績の「中」から「下」の者に多い****。 しかし「上」の者もない訳ではない。学力というものの 中に知識としてのヴォキャブラリーの如何が念まれてい

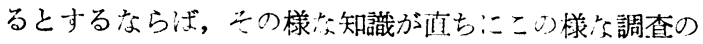

* 牛島義友：農村览童の心理, 昭 $21, \mathrm{p} 174$.

** 北海道一地教育振興会, 人考地の数育事情, 1 昭29, p 222 .

****網地島地区!区応語の一般的倾向と共にここでも 他の僻地地区に比へて幾分趣きを翼にしている。この

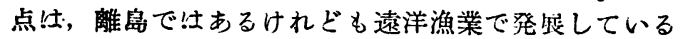
網地島の精神的風土が反映しているので!ないかと考 えられる。即ちこの地区は「閉ざされた世界」として の僻地的性格と, 開加た世界」としての非僻地的 性格との二重性格を持つ様に思われる。

**** Table 8 K念まれている様に, 都会でも東京の 4 年生飞 3 名, 未分化反応の点で「湖地的反応」型の 特徴を示す子があつた。調べて見ると 3 人共成績は下 であり，家庭の生活程度は中以下であつた。
反応語の上に現れて来るものではないとと, 二れよりも 生活室間に規制せられる反応の態度の方が物を云う場合 のあることを, 成績上位の者の存在が語つている様に思 われる。

それならばこの様な特徵を示す子供達は，反応の場に おいて他に色々な回答例のあることを予め知らされたら ぞうであろうか。この点を検傠したものが特にB票によ るテストを加えた調查である。この調查㳘，「僻地的反 応」において特徽的である子供達は，「ほしいもの」や 「したいこと」や「なりたいもの」で他の一般の子供達 が色々と挙げている様な反応のあり得ることを知らない からではないかという疑問にも答えるものである。我々 は沢内地区の 4 年生について A票による調查を行つた翌 日， $\mathrm{B}$ 票によるテストを実施し，その直後:再び $\mathrm{A}$ 票に よる調查を行つて見た。その結果は Table 11 に示され ている。 2 回目には「僻地的反応」の消減または減少し た者も確かにあるが, 一方, 依然として変らない者もあ り，それは，成績上位の者にも認められるのである。こ のことは，僻地児童固有の生活空間の規定性の強さを更 に物語るものと考える。*

（4）以上で今回の考察を終るが，我々の考察の対象 とした資料は決して十分なものではない。我々は各地域 に出向き，直接子供達に逢つて調查したのだあり，従つ て結果の考察もそれらの地域や子供達から受けたもるも ろの印象を背景として行われている。しかし地区毎には 僅か数日宛の滞在であつて，接触面も限られており，観 察の不徹底や誤りもあろう。質問紙法こよる調查の限界 もある。また僻地の子供達を知るため:こ文云の家庭生活 ・社会生活の面をも更に突込んで調べね状ならない。** 僻地の子供達の生活空間のより精密衣分析: 我々に残守 れた今後の課題である。

（5）最後に今回の調查並びに元の考察を通じて我々 は教育心理学的に如何㐫ることを反省志しらられるであ ろうか。

i 僻地の子供達に対する生活指導圾学翼指尊は彼等 の心理学的生活空間の特殊性を考慮してなされねばなら ないということである。その考虑なしに都会空標準とす

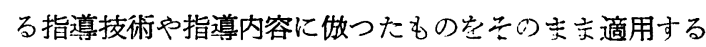
ことは，学習者の現実から遊離するお方うぶあるである

*「仕事」反応は成績の上下に余り関係がなく，か つ固執せられる傾向を示した。

**その補いの一部として館岩地区にまいては面接法 による家庭生活調査を行つた。その結果汢，更に資料 を整えた上で桶口によつて改めて報告せられる筈であ る。 
う。少くともそとには段階的な配虑を加えるととが望ま ᄂい。

ii 直接程験の世界に著しい制約を受けている子供達 を扱う僻地教育においては，視聴觉教具教材を大いに活 用すべきである。しかしその場合にも前項の留意が必要 である。

iii しかし我々は僻地の子供達の未分化性を常に前提 として僻地教育の技術を論じようとするのではない。更 に進えで僻地児童の生活空間を制的する条件の根源を蕒 き基本的对策を考元，子供達の閉さされた心の空を押し 開いてやらねはならぬ。そしでその様な根本的な方途を 講ずることが如何に容易ならざるととであるかは，僻地 の現場における我々の乏しい程験からも十二分に察せら れる。しかしこのことに敢て言及するゆええは，我々の
今回の研究も, せめてその様ないとなみを推進せしめる ためのささやかな寄与ともなるならばという思いに朋ま されて綂けられたものであるからである。

\section{[4]要 粎}

1 「要求調查」を通じての考察の結果, 僻地の子供 達と都会の子供達との相違の一面は心理学的生活空間の 構造の相違, 即ち分化度の相違に存すると考元られる。

2 僻地の子供の未分化反応は男よりも女に多く認め られる。

終りに臨み東京の児童の资料を得るために尽カして 頁いた東京都四谷第六小学校の小林博先生に心から の謝意を捧げる。 


\title{
ABSTRACTS
}

\section{RESEARCHES ON ISOLATED VILLAGE SCHOOL-CHILDREN}

\author{
Institute of Educational Psychology, Tohoku University \\ [I] THE RESULT OF “NEED TEST" ON ISOLATED \\ VILLAGE SCHOOL-CHILDREN
}

By Tsukata, Takeshi and Kubota, Masand

We studied the psychological life space of the children in isolated villages in the light of a "Need Test", a questionnaire by pencil and paper method.

The questions were directed to (1) what would you like to have, (2) what would you like to do, and (3) what would you like to be, if whatever you wish were possible to be satisfied.

Investigations were held in four remote parts of Tohoku district. The subjects, 777 pupils in total, consisted of 4 th year and 6 th year pupils of primary schools, and 2nd year pupils of junior high schools. 23.7 town pupils were examined in the same way for the purpose of comparison.

The result shows that the variability of village children's responses tends to be restricted to matters familiar to them, despite the limitless possibility offered to their answering. For example, in the responses to the first question, we find many trivial articles, such as a "pencil", " notebook", " rubber eraser", which they do not miss at home or at school; and to the second question, many domestic tasks which they are actually doing as daily routine. Such tendency was more eminent in the 4th year children than in the children in upper grades, and more persistent in girls than in boys.

We interpret the result as showing that the life space of isolated village children is lowly differentiated; and their mental development is conditioned to delay.

\section{[II] INTELLECTUAL DEVELOPMENT OF CHILDREN AND PRE-ADOLESCENTS IN ISOLATED VILLAGES}

\section{By Nakajima, Tsutomu}

It has been reported by forgoing investigators that level of intelligence is generally lower than in rural school chidren.

Our problem. was to ascertain the level of 